\section{First vs. second rotation of a poplar short rotation coppice: leaf area development, light interception and radiation use efficiency}

\author{
Laura S Broeckx, Stefan PP Vanbeveren, Melanie S Verlinden, Reinhart \\ Ceulemans
}

Given the high expectations for lignocellulosic biomass as one of the potential solutions for energy security and climate change mitigation, commercial scale studies over several rotations are crucial to assess the potential and the sustainability of short rotation coppice (SRC) cultures for bioenergy. The first and the second rotation of the SRC poplar (Populus) plantation of the present study differed significantly in biomass yield and in productivity determinants and their relationships. Coppicing enhanced leaf area development, radiation interception and woody biomass productivity. High total leaf area and radiation use efficiency (RUE) equally contributed to the high biomass yield during the establishment rotation, while RUE became the most important determinant of biomass yield after coppice. The study confirmed the significant genotypic variation in biomass productivity and its underlying determinants, also among more recently selected poplar genotypes. The absence of a correlation between intercepted radiation and RUE suggests the potential of selecting for genotypes combining high total leaf area and photosynthetic carbon uptake in future breeding programs for yield maximization towards sustainable bioenergy cultivation.

Keywords: Genotypic Variation, Leaf Area Index, Aboveground Woody Biomass Productivity, Bioenergy, Populus, POPFULL

\section{Introduction}

Energy security and greenhouse gas emission reductions are major challenges to meet the global energy demand and to mitigate climate change (IPCC 2014). In the light of these global concerns bioenergy could play a crucial role to achieve the EU's energy and climate targets (European Council 2009). The cultivation of lignocellulosic biomass, mostly poplar and willow in short rotation coppice (SRC) systems, has a high potential for the production of renewable electricity and the generation of "green" heat (Fischer et al. 2010). Despite the long-term experience with the commercial production in northern Europe (Rosenqvist et al. 2000, Lange-

veld et al. 2012), the implementation of SRC as a renewable energy crop is limited in European agriculture (AEBIOM 2010, Dimitriou et al. 2011, Don et al. 2011).

Productivity is determined by light interception and by the efficiency of converting the intercepted radiation into biomass, i.e., the radiation use efficiency (RUE), as reported for both herbaceous (Sinclair \& Horie 1989) and woody (tree) species (Cannell et al. 1988, Medlyn 1998). The crop's capacity to intercept radiation is determined by its photosynthetic area, generally assessed via the leaf area index (LAI), which is linearly related to the biomass production in poplar and willow plantations (Larson \& Isebrands

Department of Biology, Research Group of Plant and Vegetation Ecology, University of Antwerp, Universiteitsplein 1, Wilrijk B-2610 (Belgium)

@ Stefan Vanbeveren (stefan.vanbeveren@uantwerpen.be)

Received: Sep 25, 2014 - Accepted: Mar 10, 2015

Citation: Broeckx LS, Vanbeveren SPP, Verlinden MS, Ceulemans R, 2015. First vs. second rotation of a poplar short rotation coppice: leaf area development, light interception and radiation use efficiency. iForest 8: 565-573 [online 2015-04-27] URL: http://www.sisef.it/ iforest/contents/?id=ifor1457-008

Communicated by: Giorgio Matteucci
1972, Cannell et al. 1988, Taylor et al. 2001a). In SRC systems, faster canopy closure and increased growth rates of sprouts from an established root system result in enhanced productivity of coppiced versus noncoppiced tree stands (Ceulemans et al. 1996). Substantial genotypic variation exists in aboveground woody biomass productivity (AGWB) of SRC cultures in poplar (Ceulemans \& Deraedt 1999, Dillen et al. 2011, Paris et al. 2011, Benetka et al. 2014). Variation in AGWB has been explained by variation in light interception, in biomass allocation, in leaf physiological factors related to RUE or in a combination of the aforementioned (Cannell et al. 1988, Green et al. 2001, Tharakan et al. 2008), suggesting inconclusive results on the relative importance of productivity determining factors in SRC. The quantification of genetic diversity and of genetic control contributes to future tree improvement and to yield maximization efforts towards sustainable bioenergy cultivation.

In the present study, we analyzed the leaf area development, light interception and RUE of 12 poplar genotypes in a high-density SRC culture, before and after the first coppice of an experimental plantation. Assessment of LAI and woody biomass productivity was performed in a single versus a multi-stem culture, to analyze the effect of coppicing. We hypothesized significant genotypic, parentage and provenance variation in LAI, in leaf area duration (LAD), in RUE, in intercepted radiation $\left(I_{\text {int }}\right)$ and AGWB. The objectives of this study were: (i) to determine the main differences between the first (R1) and the second rotation (R2) in the above mentioned parameters and in their relationships, i.e., before and after coppice, and (ii) to determine the relative importance of the variation in LAI, LAD, $I_{\text {int }}$ and RUE in explaining the variation in AGWB during both rotations of two years.

\section{Materials and methods}

\section{Site description}

Within the framework of the POPFULL project (http://uahost.uantwerpen.be/popfull) an 18.4 ha large bio-energy plantation was established in Lochristi (Belgium) in April 2010. The former land use was a combination of agricultural uses, consisting of cropland and extensively grazed pasture. The long-term average annual temperature and precipitation at the site are $9.5{ }^{\circ} \mathrm{C}$ and 726 $\mathrm{mm}$, respectively. Meteorological parameters as air temperature, precipitation, incident solar radiation, etc. were recorded half-hourly from a meteorological station located within the plantation's boundary. Soil analyses prior to planting characterized the soil as sandy with deeper clay layers. An area of 14.5 ha was planted with dormant hardwood 
Tab. 1 - Synoptic description of the twelve poplar (Populus) genotypes planted in the operational short rotation coppice (SRC) plantation of the study. Parentage, place of origin, botanical section, year of the cross and of the commercialization and gender are presented. (D): Populus deltoides; (M): Populus maximowiczii; (N): Populus nigra; (T): Populus trichocarpa. (1): Genotypes produced by the Institute for Nature and Forest Research (INBO, Geraardsbergen, Belgium); (2): genotypes produced by the Research Institute for Forestry and Landscape Planning "De Dorschkamp" (Wageningen, The Netherlands); (3): genotype originating from an open-pollinated P. deltoides tree, first commercialized by the nursery Simon-Louis Frères (Metz, France).

\begin{tabular}{|c|c|c|c|c|c|}
\hline Genotype & Parentage & Place of origin & Section & $\begin{array}{l}\text { Year of cross/ } \\
\text { commercialization }\end{array}$ & Gender \\
\hline Bakan $^{1}$ & $\mathrm{~T} \times \mathrm{M}$ & (Washington US $\times$ Oregon US) $\times$ Japan & Tacamahaca & $1975 / 2005$ & male \\
\hline Skado $^{1}$ & $\mathrm{~T} \times \mathrm{M}$ & (Washington US $\times$ Oregon US) $\times$ Japan & Tacamahaca & $1975 / 2005$ & female \\
\hline Muur $^{1}$ & $\mathrm{D} \times \mathrm{N}$ & $($ Iowa US $\times$ Illinois US $) \times($ Italy $\times$ Belgium $)$ & Aigeiros & $1978 / 1999$ & male \\
\hline Oudenberg $^{1}$ & $\mathrm{D} \times \mathrm{N}$ & $($ Iowa US $\times$ Illinois US $) \times($ Italy $\times$ Belgium $)$ & Aigeiros & $1978 / 1999$ & female \\
\hline Vesten $^{1}$ & $\mathrm{D} \times \mathrm{N}$ & $($ Iowa US $\times$ Illinois US $) \times($ Italy $\times$ Belgium $)$ & Aigeiros & $1978 / 1999$ & female \\
\hline Ellert $^{2}$ & $\mathrm{D} \times \mathrm{N}$ & Michigan US $\times$ France & Aigeiros & $1969 / 1989$ & male \\
\hline $\mathrm{Hees}^{2}$ & $\mathrm{D} \times \mathrm{N}$ & Michigan US $\times$ France & Aigeiros & $1969 / 1989$ & female \\
\hline Koster $^{2}$ & $\mathrm{D} \times \mathrm{N}$ & Michigan US $\times$ The Netherlands & Aigeiros & $1966 / 1988$ & male \\
\hline Robusta $^{3}$ & $\mathrm{D} \times \mathrm{N}$ & Eastern US $\times$ Europe & Aigeiros & $1885 / 1890$ & male \\
\hline Grimminge $^{1}$ & $\mathrm{D} \times(\mathrm{T} \times \mathrm{D})$ & $\begin{array}{l}(\text { Michigan US } \times \text { Connecticut US }) \times \\
(\text { Washington US } \times(\text { Iowa US } \times \text { Missouri US }))\end{array}$ & $\begin{array}{l}\text { Aigeiros } \times \\
(\text { Tacamahaca } \times \text { Aigeiros })\end{array}$ & $1976 / 1999$ & male \\
\hline Brandaris $^{2}$ & $\mathrm{~N}$ & The Netherlands $\times$ Italy & Aigeiros & $1964 / 1976$ & male \\
\hline Wolterson $^{2}$ & $\mathrm{~N}$ & The Netherlands & Aigeiros & $1960 / 1976$ & female \\
\hline
\end{tabular}

cuttings at a density of $8000 \mathrm{ha}^{-1}$. A doublerow design was used, with alternating distances of 0.75 and $1.50 \mathrm{~m}$ between the rows and $1.1 \mathrm{~m}$ between the individual trees within the row. No irrigation or fertilization was applied. The plantation was monitored during two consecutive rotations of two years $(2+2)$. A first harvest was performed in February 2012, creating a multi-stem coppice culture, and a second harvest was performed in February 2014. Only after the first harvest a chemical treatment was applied in the spring to reduce the impact of poplar beetles on the young leaves of the resprouts. Pathogen attacks or other biotic influences were not monitored, but no significant impacts of pests or diseases were noticed during the four years of the study. More detailed information on site and soil characteristics, as well as on plantation management can be found in Broeckx et al. (2012) and Verlinden et al. (2013).

Twelve selected poplar (Populus) genotypes, all commercially available, were planted in large monoclonal blocks of eight doublerows wide. The replicated blocks covered both former land use types and varied in length between 90 and $340 \mathrm{~m}$. The genotypes represented different species and hybrids of Populus deltoides Bartr. (ex Marsh) $P$. maximowiczii Henry, $P$. nigra L. and $P$. trichocarpa Torr \& Gray (ex Hook - Tab. 1).

\section{Leaf area development}

Leaf area development was assessed throughout each of the four growing seasons using regular indirect measurements of the leaf area index (LAI). The LAI-2000 (first growing season, GS1) and LAI-2200 (growing seasons two to four, GS2-4) Plant Canopy Analyzers (LiCor, Lincoln, NE, USA) were used to measure plant area index
(PAI), by comparison of above- and belowcanopy readings with a $45^{\circ}$ view cap. The measurements were performed in 48 (GS1) and 96 (GS2-4) plots, representing two and four replicates respectively per genotype and per former land use type. In each plot, two diagonal transects of four (GS1) and three (GS2-4) readings each, were made crossing the different row distances and representing the different degrees of canopy closure. Along each transect, measurements were taken with the sensor parallel and perpendicular to the row, according to the measurement protocol for row crops described in the instrument instruction manual (LAI-2200, version 1.0).

PAI was converted to LAI, by correcting for the branch area index (BAI). BAI was derived from PAI measurements of the winter status of the trees. Increment of the BAI throughout the growing season was assumed linear, between the start of leaf area development and the end of leaf fall, i.e., the period of leaf expansion. The calculated BAI was subtracted from each corresponding PAI measurement, yielding the effective LAI.

Indirect LAI measurements were validated by direct assessments of seasonal maximum LAI $\left(\mathrm{LAI}_{\max }\right)$. Leaf litter was collected in three $0.57 \times 0.39 \mathrm{~m}$ litter traps, placed along a diagonal transect in all (GS1) and half (GS2-4) of the measurement plots of the indirect LAI measurements. The litter traps were emptied every two weeks, and leaf dry mass was cumulated for each plot. Specific leaf area (SLA, $\mathrm{m}^{2} \mathrm{~kg}^{-1}$ ), defined as the ratio between fresh leaf area and leaf dry mass, was determined per genotype for each growing season around the time of $\mathrm{LAI}_{\max }$ (Verlinden et al. 2013). $\mathrm{LAI}_{\max }$ was determined from the cumulated dry mass of the leaf litter using the genotype specific SLA. Direct
$\mathrm{LAI}_{\max }$ values were linearly correlated to $\mathrm{LAI}_{\max }$ reached in the corresponding plots based on indirect LAI measurements.

Leaf area duration (LAD, $\mathrm{m}^{2}$ day $\mathrm{m}^{-2}$ ) was calculated as the integrated area below the seasonal LAI curve of each plot (Ceulemans \& Deraedt 1999, Dowell et al. 2009). The starting point of the curve, representing the beginning of the growing season, was based on visual phenological observations of bud break, using previously described arbitrary discrete classes (Turok et al. 1996, Pellis et al. 2004). The end of the growing season was determined by fitting a (non-linear) curve through the gradual collection of leaf fall, until $100 \%$ leaf fall.

\section{Light interception and radiation use efficiency (RUE)}

Radiation use efficiency (RUE, $\mathrm{g} \mathrm{MJ}^{-1}$ ) was calculated as the quotient of aboveground woody biomass productivity (AGWB - see below) and incoming short-wave radiation $\left(I_{0}\right)$. In addition, RUE was expressed in terms of percentage using an energy density of $19.5 \mathrm{GJ} \mathrm{Mg}^{-1}$ dry mass of wood (Serup et al. 2005). The intercepted short-wave radiation $\left(I_{\text {int }}\right)$ was calculated based on the BeerLambert equation (eqn. 1):

$$
I_{\text {int }}=I_{0}-I_{t r}=I_{0}\left(1-e^{-k \cdot L A I}\right)
$$

where $I_{\text {tr }}$ is the radiation transmitted through the canopy and $k$ is the extinction coefficient. Incoming short-wave radiation (0.3-3 $\mu \mathrm{m})$ was continuously recorded with a pyranometer (CNR1, Kipp \& Zonen, Delft, The Netherlands) and half-hourly averages were logged $\left(\mathrm{W} \mathrm{m}^{-2}\right)$, multiplied by $1800 \mathrm{~s}\left(\mathrm{~J} \mathrm{~m}^{-2}\right)$ and summed over the growing season. Direct $\mathrm{LAI}_{\max }(\mathrm{GS} 1-2)$ and indirect $\mathrm{LAI}_{\max }$ corrected for BAI (GS3-4) were used to calculate $k$ 
from the converted Beer-Lambert equation (eqn. 2):

$$
k=\frac{-\ln \left(I_{t r} / I_{0}\right)}{L A I}
$$

where $I_{\mathrm{tr}} / I_{0}$ was taken from the LAI-2200 measurements at $\mathrm{LAI}_{\max }$, using the proportion of incoming radiation on the sensor angled between $7^{\circ}$ and $53^{\circ}$ zenith (Verlinden et al. 2013). $I_{\text {int }}$ was expressed as the percentage of total incoming radiation during the growing season $\left(I_{\text {int }} / I_{0} \cdot 100\right)$.

\section{Woody biomass}

At the end of each growing season, the standing woody biomass was estimated from a diameter inventory of the winter habitus of the trees (described in detail by Verlinden et al. 2013). Genotype specific allometric relationships between stem diameter at $22 \mathrm{~cm}$ height and (harvestable) stem biomass were established at the end of each rotation, in December 2011 and in January 2014 (Broeckx et al. 2014a). To this end, ten stems per genotype covering the frequency distribution of the stem diameter inventory of the entire plantation were harvested at $15 \mathrm{~cm}$ above soil level. This corresponded to the mean harvesting height at the plantation (Berhongaray et al. 2013). Stem diameter at $22 \mathrm{~cm}$ $(D)$ was plotted against stem dry mass $(D M)$, after oven drying at $70{ }^{\circ} \mathrm{C}$ until constant weight, and an exponential curve was fitted for each genotype (eqn. 3):

$$
D M=a \cdot D^{b}
$$

resulting in genotype specific regression coefficients $a$ and $b$, used to estimate the standing biomass. Trees closest to the location of the LAI-measurement plots were selected from the diameter inventory.

Aboveground woody biomass productivity (AGWB) was defined as the annual woody biomass dry mass in each growing season studied $\left(\mathrm{Mg} \mathrm{ha}^{-1}\right.$ year $\left.^{-1}\right)$. The biomass yield was defined as the standing (harvestable) woody biomass at the end of each rotation, representing the sum of AGWB of two consecutive growing seasons for each plot $(\mathrm{Mg}$ ha $^{-1}$ rotation $^{-1}$ ).

\section{Statistical analysis}

Linear and non-linear relationships between the studied parameters $\left(\mathrm{LAI}_{\max }, \mathrm{LAD}\right.$, $I_{\text {int }}$, RUE and AGWB) were fitted in SigmaPlot $^{\mathbb{B}}$ version 12.5 (Systat Software, San Jose, CA, USA). Non-parametric Spearman's rank correlation analyses were used to test for significant correlations between genotypic averages of the studied parameters for each growing season. Averages per genotype were used, which were normally distributed, according to a Shapiro-Wilk normality test. Nevertheless, non-parametric tests were used because the sample size was only twelve (one average value per genotype), which was considered not trustworthy for a parametric test. Relationships between production related characteristics and yield (plot averages per rotation) were analyzed using Pearson's correlation coefficients. A generalized linear model (GLM) was fitted in SPSS $^{\circledR}$ (IBM Corp., SPSS Statistics for Windows, Armonk, NY) as a non-parametric test to study significant differences between genotypes and parentage groups in the studied parameters.

\section{Results}

Direct and indirect assessments of $\mathrm{LAI}_{\max }$ were closely related as shown in Fig. 1a. Before coppice (GS1-2) there was a strong correlation $\left(\mathrm{R}^{2}\right.$ values of 0.69 and 0.74 , respectively) between both methodologies, with a minor underestimation of the indirect method for larger LAI values. After coppice (GS3-4) the correlations between direct and indirect measurements were weaker but still significant $\left(\mathrm{R}^{2}\right.$ values of 0.60 and 0.58 , respectively), with an overall overestimation of the indirect method. Several potential causes explain the small discrepancies between the direct and indirect LAI measurements: (i) the rapid canopy closure in the multi-stem culture after coppice could have caused early leaf fall due to shading of the lower crown parts, that were not collected in the leaf litter traps installed only near the end of the growing season; (ii) larger amounts of leaf fall in the litter traps after coppice enhanced leaf decomposition before emptying the litter traps; (iii) the multi-stem coppice structure hampered placement of the litter traps close to the stump of the tree, which might have reduced the representativeness of the plot area covered by the litter traps; (iv) the multi-stem coppice structure increased the risk of shading the sensor by lower leaves/branches close to the sensor in the dense canopy. Although both methods have their inherent limitations, we considered the indirect LAI values a validated representation of the effective LAI. Therefore, indirect assessments of LAI were used in all further analyses. BAI - at the time of $\mathrm{LAI}_{\max }$ - increased throughout the consecutive growing seasons (Fig. 1b) from 0.16 (on average) in 2010 to 0.76 (on average) in 2013. However, the relative contribution of BAI to maximum PAI was reduced in the first growing season after coppice $(6.4 \%$ in GS3) as compared to the other growing seasons $(13.4 \%, 12.9 \%$ and $14.1 \%$ in GS1, GS2 and GS4, respectively - Fig. 1b).

The time course of $\mathrm{T}_{\text {air }}, I_{0}$ and LAI for the four years of observation is shown in Fig. 2 . The four years were similar in terms of the average temperature and incident radiation. The average annual and average growing season $\mathrm{T}_{\text {air }}$ were 9.8 and $14.5{ }^{\circ} \mathrm{C}$ in 2010 ; 11.5 and $14.9^{\circ} \mathrm{C}$ in $2011 ; 10.5$ and $14.3{ }^{\circ} \mathrm{C}$ in 2012; and 10.1 and $13.8{ }^{\circ} \mathrm{C}$ in 2013 , respectively. The annual and growing season
Fig. 1 - Genotypic averages (a) of direct $v s$. indirect maximum leaf area index $\left(\mathrm{LAI}_{\max }\right)$, and (b) of branch area index (BAI) in relation to plant area index (PAI) in four consecutive growing seasons: first rotation before coppice (GS1 and GS2) and second rotation after coppice (GS3 and GS4).

Error bars indicate standard deviations, regression lines represent significant Spearman's rank correlations $(\mathrm{p}<0.05$; solid line $=\mathrm{GS} 1$, dashed line $=\mathrm{GS} 2$, dotted line $=\mathrm{GS} 3$, and dash-dotted line $=$ GS4)
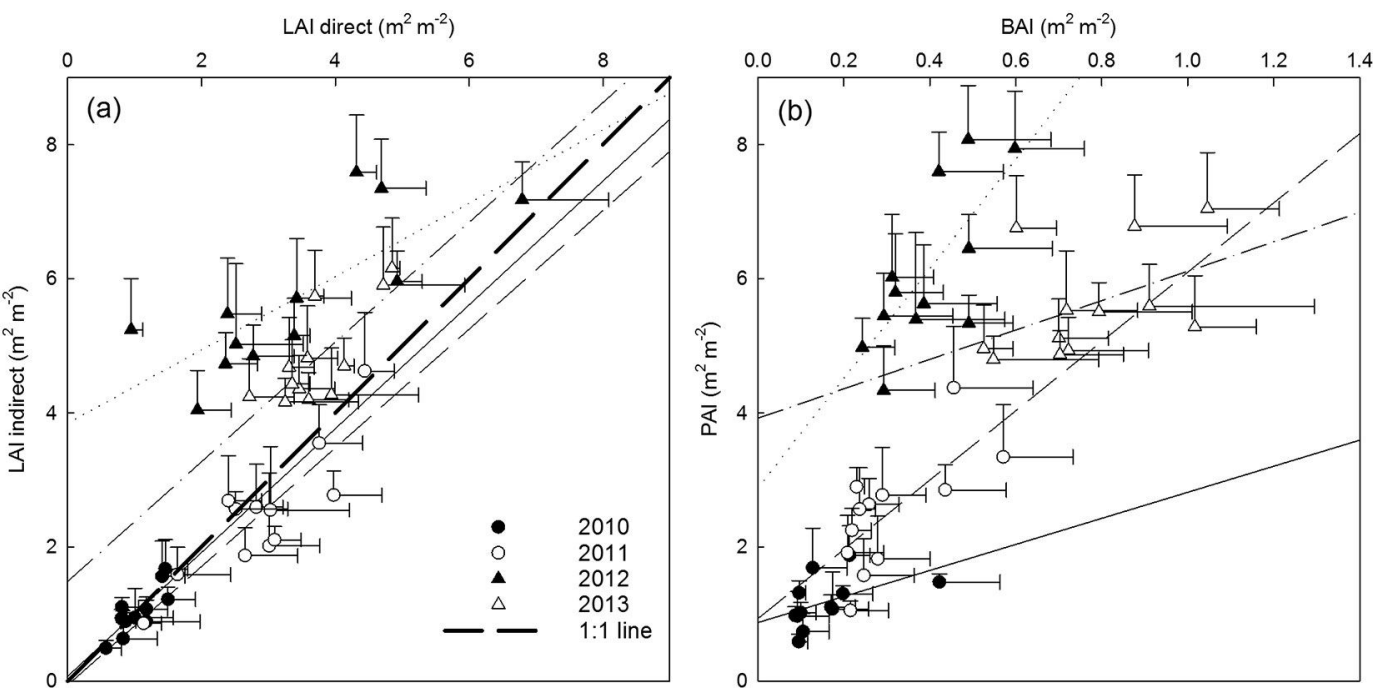


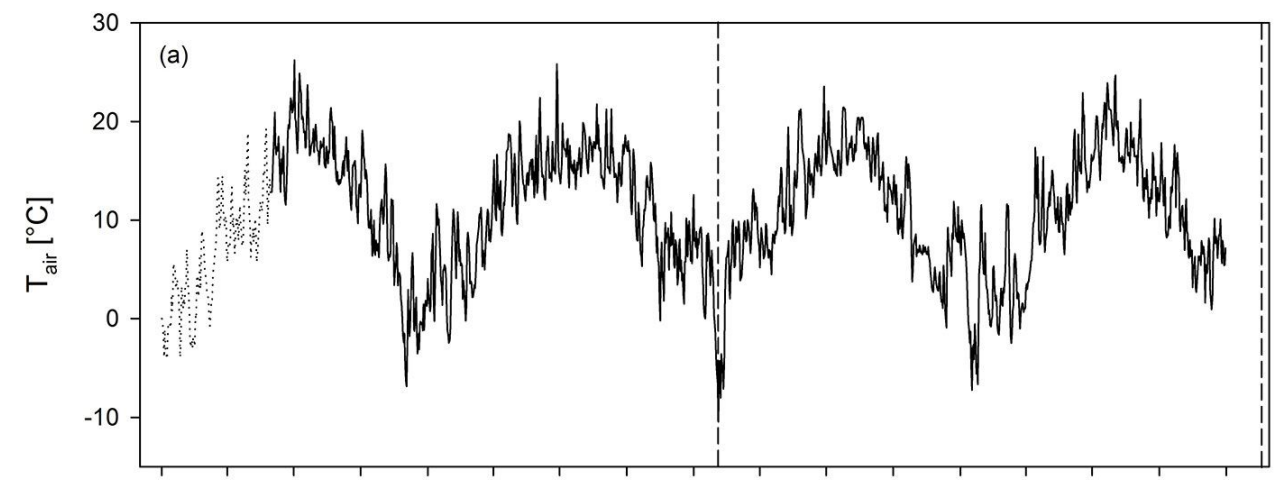

Fig. 2 - Seasonal time course of (a) air temperature $\left(\mathrm{T}_{\text {air }}\right),(\mathrm{b})$ incoming shortwave radiation $\left(I_{0}\right)$ and (c) leaf area index $(\mathrm{LAI} \pm$ standard deviation and genotypic maximum and minimum values) during four growing years (two rotations; GS1-4). Dashed vertical lines indicate the time of coppice of the entire plantation.
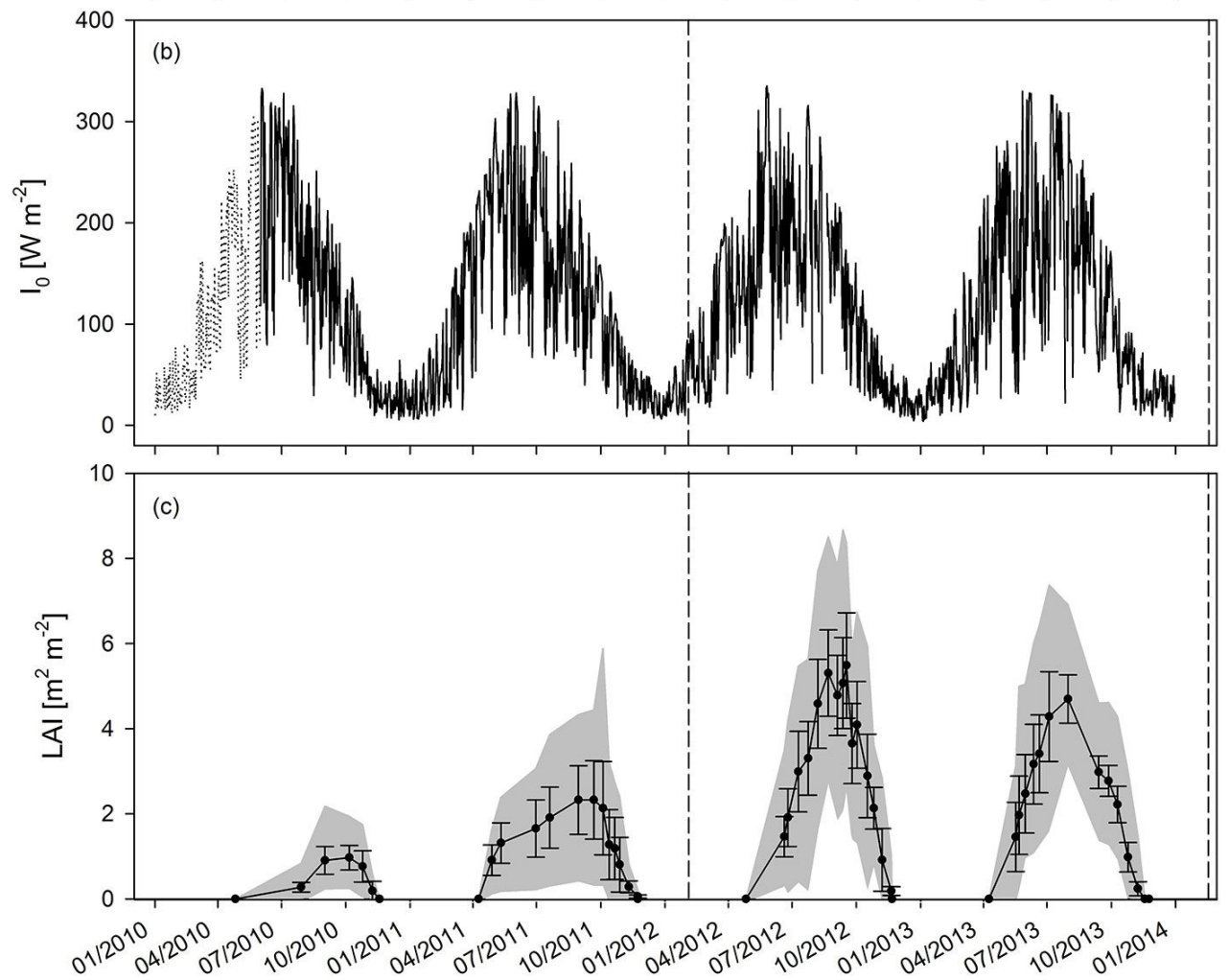
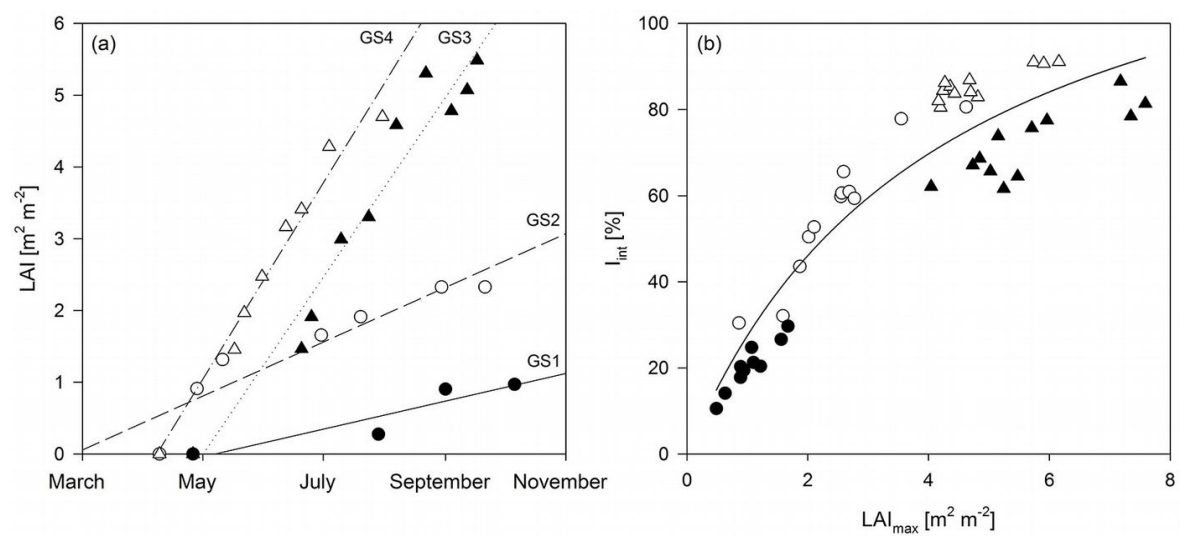

Fig. 3 - (a) Evolution of leaf area index (LAI) until maximum LAI was reached, and (b) the overall (hyperbolic) relationship between maximum leaf area index $\left(\mathrm{LAI}_{\max }\right)$ and intercepted radiation $\left(I_{\text {int }}\right)$ over four years of the short-rotation coppice $\left(I_{\text {int }}=143.13 \cdot \mathrm{LAI}_{\max } /(4.21+\right.$ $\left.\left.\mathrm{LAI}_{\max }\right)-\mathrm{R}^{2}=0.88\right)$. Solid and open circles indicate the first and second growing seasons (GS1 and GS2, respectively), before coppice; solid and open triangles indicate GS3 and GS4, respectively, after coppice. The slopes of the fitted curves in (a) indicate leaf area increment rate. Intercepts and $\mathrm{R}^{2}$ were 0.0063 and 0.86 in GS1; 0.0123 and 0.87 in GS2; 0.0404 and 0.95 in GS3; 0.0448 and 0.97 in GS4, respectively. sums of $I_{0}$ were 37 and $28 \mathrm{TJ}^{-1} \mathrm{ha}^{-1}$ in 2010 ; 38 and $31 \mathrm{TJ} \mathrm{ha}^{-1}$ in 2011;37 and $28 \mathrm{TJ} \mathrm{ha}^{-1}$ in 2012; and 37 and $30 \mathrm{TJ} \mathrm{ha}^{-1}$ in 2013, respectively. The development of leaf area during the growing season closely followed the evolution of $\mathrm{T}_{\text {air }}$ and $I_{0}$ as presented in Fig. 2. The LAI reached maxima of 0.97 and 2.33 (averaged over the entire plantation) in GS1 and GS2 (before coppice), respectively, and of 5.49 and 4.70 in GS3 and GS4 (after coppice), respectively. Therefore, $\mathrm{LAI}_{\max }$ increased up to the third growing season, and reached a plateau during R2. The rate of LAI increment over time strongly increased in R2 (Fig. 3a) as a result of the coppicing. Within each rotation, a similar slope of LAI increment rate was observed between the two growth years. The curve was shifted upward due to an earlier start of leaf area development in the non-coppice years within each rotation (i.e., second growing season of each rotation - Fig. 3a). The slope of the curves 


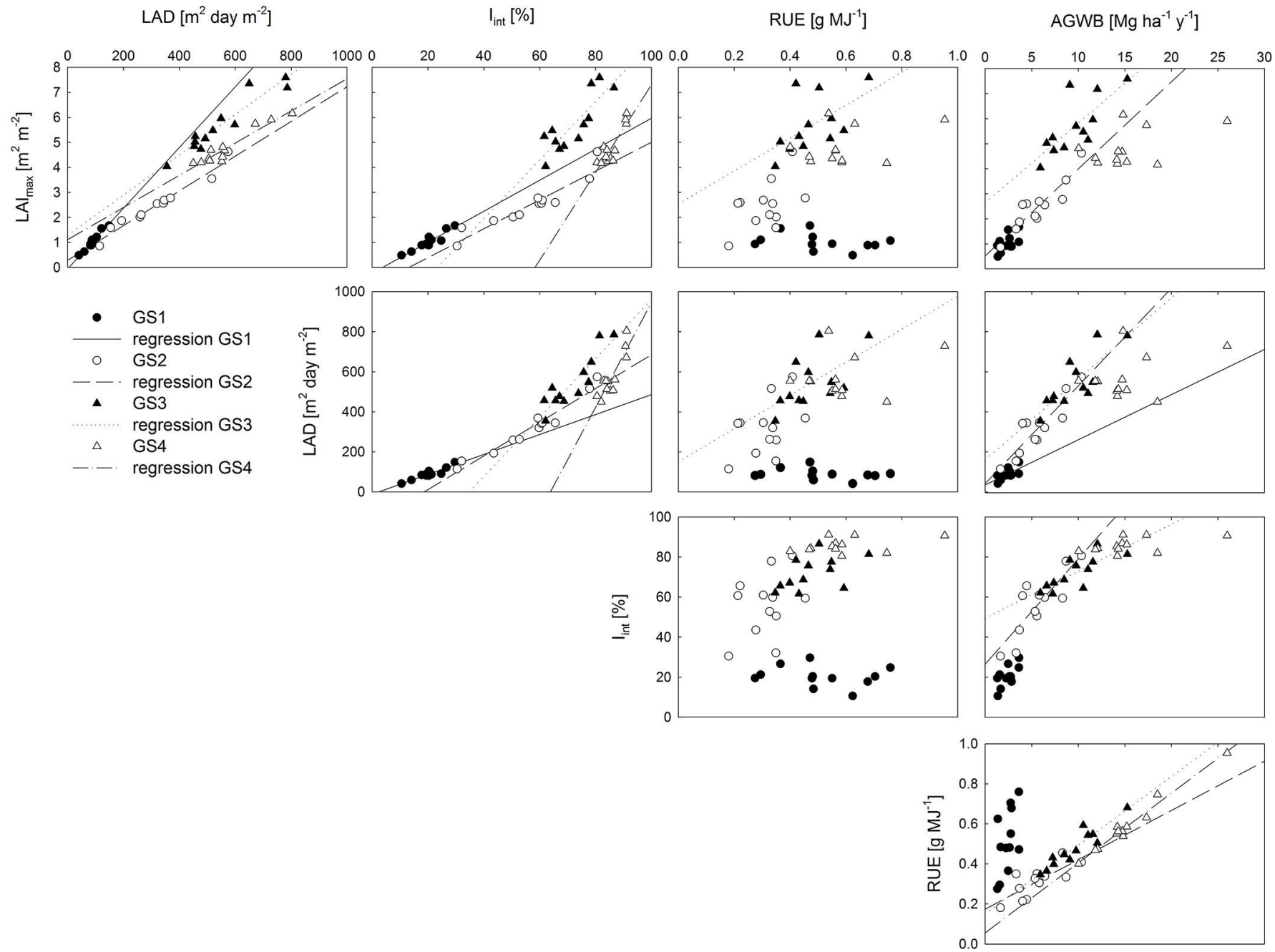

Fig. 4 - Correlation matrix of production-related characteristics: maximum leaf area index $\left(\mathrm{LAI}_{\max }, \mathrm{m}^{2} \mathrm{~m}^{-2}\right)$, leaf area duration $\left(\mathrm{LAD}, \mathrm{m}^{2}\right.$ day $\left.\mathrm{m}^{-2}\right)$, intercepted radiation $\left(I_{\mathrm{int}}, \%\right)$, radiation use efficiency $\left(\mathrm{RUE}, \mathrm{g} \mathrm{MJ}^{-1}\right)$ and aboveground dry woody biomass production $(\mathrm{AGWB}, \mathrm{Mg}$ $\mathrm{ha}^{-1}$ ). Data points represent genotypic averages; regression lines represent significant Spearman's Rank correlations $(\mathrm{p}<0.05)$.

strongly increased from R1 to R2, thus in the coppiced culture the leaf area increment rate was higher as compared to the non-coppiced culture. With increasing $\mathrm{LAI}_{\max }$ over the course of the different growing seasons, also $I_{\text {int }}$ increased (Fig. 3b). As expected from the Beer-Lambert equation, this correlation was well described by a common logarithmic pattern.

The correlation among the studied parameters, as well as their relationship to AGWB, varied among the different years of observation (Fig. 4). The (semi-auto) correlation between $\mathrm{LAI}_{\max }$ and LAD was significant in all growing seasons, as was the correlation between $\mathrm{LAI}_{\max }$ (and hence LAD) and $I_{\text {int }}$. Overall, the variation in LAI and LAD explained the variation in $I_{\text {int }}$ better than the variation in $A G W B$. $\mathrm{LAI}_{\max }$ and $\mathrm{LAD}$ were significantly related to RUE in GS3 only, i.e., the first year after coppice. No significant correlation was found between $I_{\text {int }}$ and RUE in any of the studied growing seasons.
$\mathrm{LAI}_{\max }$ and $I_{\text {int }}$ were significantly correlated to AGWB in GS2 and GS3, while LAD was significantly correlated to AGWB in GS1 as well, in addition to GS2 and GS3. A significant correlation was found between RUE and AGWB in all growing seasons except in the establishment year (GS1 - Fig. 4). The biomass yield at the end of both rotations was significantly and positively related with the rotation sums of LAD and $I_{\text {int }}$ as well as with the RUE averaged over each rotation (Tab. 2). The Pearson correlation coefficients with biomass yield were similar for the studied parameters in R1, while RUE was the strongest determinant of biomass yield in R2 (Tab. 2).

Significant genotypic and parentage variation was observed in all studied parameters (Fig. 5, Appendix 1). In R1 a threefold variation in LAI $_{\max }\left(0.49-1.68 \mathrm{~m}^{2} \mathrm{~m}^{-2}\right)$ and LAD (40.5-148.1 $\mathrm{m}^{2}$ day $\mathrm{m}^{-2}$ ) was found among the different genotypes during the establishment year, which even increased in GS2
(0.87-4.63 $\mathrm{m}^{2} \mathrm{~m}^{-2}$ and $114.4-574.1 \mathrm{~m}^{2}$ day $\mathrm{m}^{-2}$, respectively). This was in line with the genotypic variation in AGWB (1.37-3.65 $\mathrm{Mg} \mathrm{ha}^{-1}$ in GS1 and $1.65-10.36 \mathrm{Mg} \mathrm{ha}^{-1}$ in GS2) as well as in $I_{\text {int }}(10.6-29.7 \%$ in GS1 and $30.43-80.59 \%$ in GS2). Genotype Hees was the best performing genotype, showing

Tab. 2 - Pearson correlation coefficients between production related characteristics and biomass yield of the first $(\mathrm{R} 1, \mathrm{n}=48)$ and second $(\mathrm{R} 2, \mathrm{n}=96)$ rotation. (LAD): leaf area duration; (RUE): radiation use efficiency; $\left(I_{\text {int }}\right)$ : intercepted radiation.

\begin{tabular}{llcc}
\hline Rotation Parameter & $\begin{array}{c}\text { Yield } \\
\text { R1 }\end{array}$ & $\begin{array}{c}\text { Yield } \\
\text { R2 }\end{array}$ \\
\hline R1 & LAD & $0.764^{* * *}$ & - \\
& RUE & $0.768^{* * *}$ & - \\
& $I_{\text {int }}$ & $0.721^{* * *}$ & - \\
\hline R2 & LAD & - & $0.563^{* * *}$ \\
& RUE & - & $0.973^{* * *}$ \\
& $I_{\text {int }}$ & - & $0.570^{* * *}$ \\
\hline
\end{tabular}




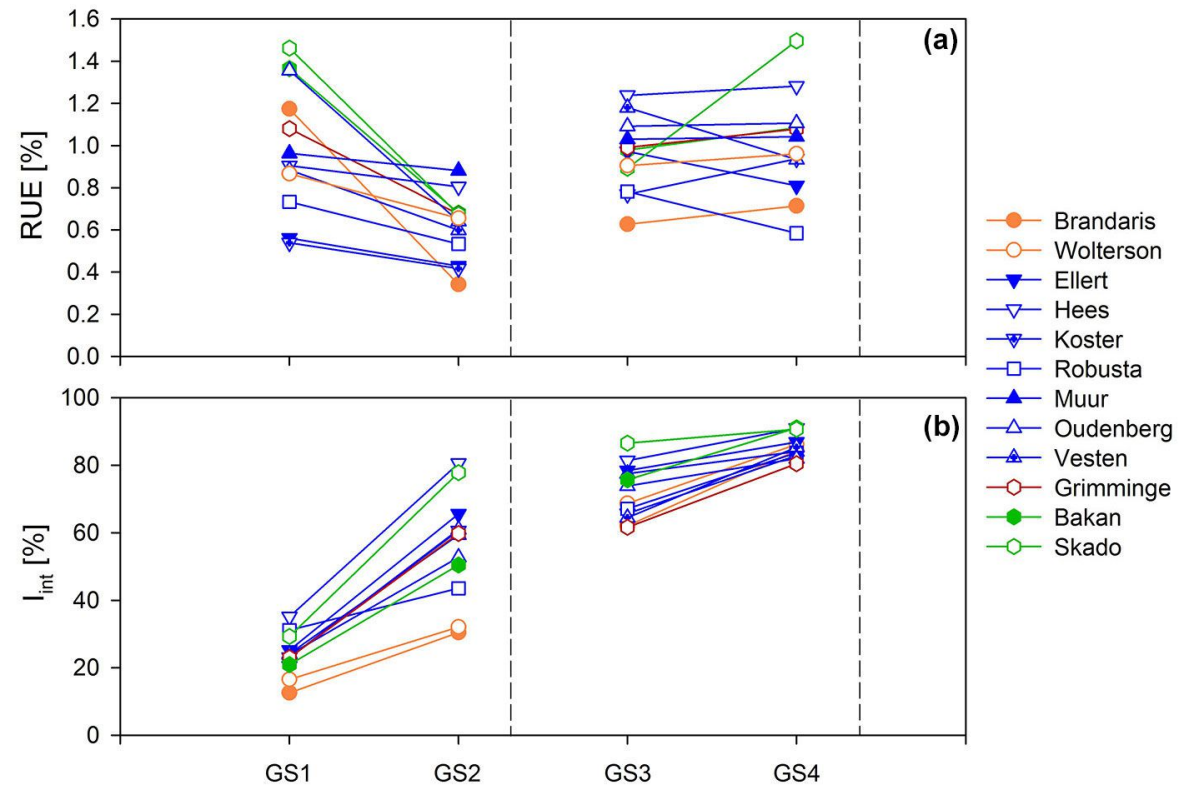

Fig. 5 - Genotypic annual averages of (a) radiation use efficiency (RUE), and (b) intercepted radiation $\left(I_{\mathrm{int}}\right)$ for twelve poplar genotypes during two consecutive two-year rotations of short rotation coppice. Colors indicate parentage groups (explained in Tab. 1), dashed lines indicate the time of coppice of the entire plantation.

the highest values for $\mathrm{LAI}_{\max }, \mathrm{LAD}, \mathrm{AGWB}$ and $I_{\text {int }}$ throughout R1. Genotype Brandaris performed weakest (Appendix 1). When all genotypes were considered, RUE ranged from 0.54 to $1.46 \%\left(0.28-0.76 \mathrm{~g} \mathrm{MJ}^{-1}\right)$ in GS1 and from 0.34 to $0.88 \%(0.21-0.45 \mathrm{~g}$ $\mathrm{MJ}^{-1}$ ) in GS2 (Fig. 5, Appendix 1). A change in genotypic ranking was observed from GS1 to GS2.

Overall, genotypic as well as within-genotype variability decreased towards $\mathrm{R} 2$, as indicated by a decreasing coefficient of variation for all studied parameters (Appendix 1). For example, the genotypic variation in $I_{\text {int }}$ gradually decreased with a progressively closing canopy (Fig. 5). The genotypic variation in $\mathrm{LAI}_{\max }\left(4.05-7.59 \mathrm{~m}^{2} \mathrm{~m}^{-2}\right.$ in GS3 and 4.17$6.16 \mathrm{~m}^{2} \mathrm{~m}^{-2}$ in GS4) and in LAD (355.0$785.8 \mathrm{~m}^{2}$ day $\mathrm{m}^{-2}$ in GS3 and 449.5-803.8 $\mathrm{m}^{2}$ day $\mathrm{m}^{-2}$ in GS4) was considerable (almost twofold). The variation in $\mathrm{LAI}_{\max }$ and $\mathrm{LAD}$ was smaller than the threefold variation in AGWB in GS3 (5.93-15.28 $\mathrm{Mg} \mathrm{ha}^{-1}$ ), but corresponded to the twofold variation in AGWB in GS4 (11.83-26.00 $\left.\mathrm{Mg} \mathrm{ha}^{-1}\right)$. In contrast to R1, this was not in line with the variation in $I_{\text {int }}$ which varied only $5 \%$ in GS4 (Fig. 5, Appendix 1). Genotypes Hees and Skado were among the best performers in GS3 (highest biomass yield); genotypes Bakan and Skado performed best in GS4. The lowest growth performance was observed in genotype Brandaris in GS3, in line with R1. In GS4, genotypes Oudenberg and Grimminge scored lowest in terms of LAI development; genotypes Koster and Robusta had the lowest AGWB and RUE (Appendix 1).
The range of genotypic average RUE increased from GS3 $(0.63-1.24 \%$ or $0.35-0.68 \mathrm{~g}$ $\left.\mathrm{MJ}^{-1}\right)$ to GS4 $(0.58-1.50 \%$ or $0.40-0.95 \mathrm{~g}$ $\mathrm{MJ}^{-1}$ ), with shifts in genotypic ranking (Fig. $5)$.

Significant differences among parentage groups were found for all the studied parameters, with the exception of RUE in GS2 (Appendix 1). After the establishment year, the $\mathrm{T} \times \mathrm{M}$ genotypes showed the highest growth performance, but the difference with $\mathrm{D} \times \mathrm{N}$ and $\mathrm{D} \times(\mathrm{T} \times \mathrm{D})$ genotypes was only significant in GS4. The lowest growth performance was observed for the $\mathrm{N}$ genotypes, but AGWB was significantly lower than for all other parentage groups in GS2 only.

\section{Discussion}

\section{Determinants of biomass yield}

The average LAI close to 1 during the establishment year was within the range of values reported for one-year old high density poplar plantations (Michael et al. 1988, Scarascia-Mugnozza et al. 1989). The values of $\mathrm{LAI}_{\max }$ observed during the consequent growing seasons were comparable to values reported for various willow (Lindroth et al. 1994, Tharakan et al. 2008, Petzold et al. 2010) and poplar SRC cultures (Ceulemans et al. 1996, Liberloo et al. 2006, Al Afas et al. 2008, Fischer et al. 2013). The seasonal evolution of leaf area development with a maximum near the end of the summer reflects the indeterminate deciduous growth habit of poplar and confirmed earlier reports for poplar (Ceulemans et al. 1996, Howe et al. 2000, Fischer et al. 2013) and willow (Lindroth et al. 1994, Guidi et al. 2008, Tharakan et al. 2008). LAI and leaf area increment rate increased significantly after coppice, from the first to the second rotation confirming the positive effect of coppicing on leaf area development and canopy closure (Rae et al. 2004, Tharakan et al. 2008). Reduced LAI after coppice has only been observed in poplar as a result of insect damage (Proe et al. 2002). Insect damages were not actively monitored in our experiment, but neither insect populations nor other leaf pathogens exerted a significant influence.

$\mathrm{LAI}_{\max }$ increased during the first rotation but saturated during the second rotation. This suggests that a stable LAI was reached during the second rotation in contrast to previous observations in poplar SRC (Al Afas et al. 2008). This could be potentially explained by increasing self-shading and leaf shedding in the lower crown parts after canopy closure in the multi-stem culture (after coppice). From our observations, the crown depth moved upwards with the growing trees from GS3 to GS4, confirming this hypothesis. The leaves or canopy reached almost until soil level in GS3, while a considerable leafless part of the stems was observed in the lower crown parts in GS4. When radiation interception was higher than $90 \%$ LAI decreased after canopy closure in a willow SRC (Bullard et al. 2002). A saturating $I_{\text {int }}$ with LAI confirmed that a further increase of LAI did not contribute to a higher radiation interception (Binkley et al. 2013). In SRC the annual radiation interception is influenced by early leaf display (spring leaf area development - Proe et al. 2002). The reduced LAI at the start of the growing season after coppice was, however, largely compensated for by the accelerated leaf area development, explaining the increasing $I_{\text {int }}$ over the four years of the two rotations.

Since the RUE values were based on the interception of total solar radiation, the values should be multiplied by two approximately in order to be compared to RUE values based on the interception of photosynthetically active radiation (PAR, 0.4-0.7 $\mu$; Cannell et al. 1987, Ceulemans et al. 1996), as frequently reported in the literature. Doubled values observed in this study were very high during the establishment year as compared with the establishment year of another poplar SRC (Deraedt \& Ceulemans 1998). This difference could be partly explained (i) by the favorable growth conditions (i.e., high nutrient availability of former agricultural land - Verlinden et al. 2013) and hence the high survival and growth rates; and (ii) by to different below- $v s$. aboveground biomass allocation, which potentially favored aboveground more in the present study due to the high nutrient status of the soil (Broeckx et al. 2012). However, the RUE observed in this 
study was in the lower end of the range reported for well-established poplar (Ceulemans et al. 1996, Heilman et al. 1996, Green et al. 2001) and willow SRC cultures (Ruimy et al. 1994, Bullard et al. 2002, Tharakan et al. 2008). Overall, the plantation average radiation use efficiency of $0.7 \%$ in $\mathrm{R} 1$ and $1 \%$ in R2 was in line with the energy use efficiencies of less than $1 \%$ for most woody species reported by Larcher (2003).

We see two possible explanations for the decrease in RUE from GS1 to GS2, both in absolute numbers and in the genotypic range: (i) a few short periods of dry soil conditions at high solar radiation in GS2 (Broeckx et al. 2014a) might have limited leaf area development; (ii) the high genotypic variation in RUE during GS1 could also be attributed to genotypic differences in cutting quality (diameter, water content, rooting capacity, etc.). The latter might have resulted in a different allocation to the various tree compartments. After coppice (in GS3-GS4) RUE increased as compared to GS2. This increase is potentially the result of the higher carbon stocks in the roots, the high photosynthetic rates of the resprouting stumps and the limited self-shading shortly after coppice (Ceulemans et al. 1996).

\section{Genotypic variation}

Across genotypes, LAD, $I_{\text {int }}$ and RUE were all strong and reliable determinants of biomass yield during the first rotation. The relative importance of RUE in explaining the variation in biomass yield increased during the second rotation, when LAI and $I_{\text {int }}$ saturated. These results confirm previous observations of a strong correlation between RUE and $\mathrm{AGWB}$, whereas $I_{\text {int }}$ was unrelated to AGWB in high density poplar plantations (Green et al. 2001). Similarly, lower AGWB rather than reduced LAI and $I_{\text {int }}$ negatively affected RUE in willow SRC in Sweden (Linderson et al. 2007). The relative importance of both factors, $I_{\text {int }}$ and RUE, varies with levels of competition within the canopy in willow (Bullard et al. 2002, Tharakan et al. 2008). Maximum AGWB was achieved by a combination of high $I_{\text {int }}$ and a high RUE after coppice (Tharakan et al. 2008).

The fraction of intercepted radiation is determined by LAI, LAD and canopy structure (leaf and branch morphology and orientation - Cannell 1989). Canopy structure seemed less important than the amount of foliage in high density plantations (Ceulemans et al. 1996). The strong correlations of both LAI and LAD with $I_{\text {int }}$ reported here were in line with these findings. Besides LAI, LAD and canopy structure, RUE is also influenced by leaf photosynthetic capacity and by the allocation pattern of photosynthates to different tree compartments (Isebrands et al. 1983 Tschaplinski \& Blake 1989). As we found no correlation between genotypic means of
$I_{\text {int }}$ and RUE, there might have been an effect of photosynthesis and/or partitioning of assimilates on the conversion efficiency of radiation energy in woody biomass. Superior growth of poplar SRC is, however, not always associated with different allocation patterns, as shown for different hybrids and $P$. deltoides clones (Dowell et al. 2009). Genotypic variation in photosynthesis is related to leaf structural (e.g., leaf mass per area, LMA) and biochemical (e.g., leaf $\mathrm{N}$ concentration) parameters (Casella \& Ceulemans 2002, Xu \& Baldocchi 2003, Broeckx et al. 2014b). Significant genotypic differences have already been documented for LMA, leaf $\mathrm{N}$ concentration, maximum carboxylation rate $\left(\mathrm{V}_{\mathrm{c} \max }\right)$ and other photosynthetic parameters (Casella \& Ceulemans 2002, Verlinden et al. 2013, Broeckx et al. 2012, 2014b).

The significant genotypic and parentage variation in leaf area development (LAI and LAD - Liberloo et al. 2005, Dillen et al. 2009, Pellis et al. 2004) and light use efficiency $\left(I_{\text {int }}\right.$, RUE and AGWB - Deraedt \& Ceulemans 1998, Green et al. 2001, Calfapietra et al. 2003, Dillen et al. 2011, Paris et al. 2011) confirmed previous observations in poplar, although for other interspecific hybrids and genotypes. Smaller variation within related genotypes suggests a genetic control of the studied parameters. The above mentioned relationships with AGWB indicate shifts in the relative contribution of these parameters to yield over the years and rotations of the plantation. For example, during the establishment year genotypic variation in $\mathrm{LAI}_{\max }, I_{\text {int }}$ and RUE did not explain variation in AGWB. These results suggest that yield improvement by selecting genotypes for specific growth parameters should take planting density, and consequently canopy light penetration, into account.

\section{Conclusions}

Coppicing enhanced leaf area development, radiation interception and woody biomass productivity of the studied SRC poplar plantation. High total leaf area and RUE equally contributed to the high biomass yield during the establishment phase, while RUE became the most important determinant of biomass yield after coppice. The absence of a correlation between $I_{\text {int }}$ and RUE suggests the potential of selecting for genotypes combining high LAI and photosynthetic capacity, to maximize yield and sustainability of poplar SRC cultures.

\section{Acknowledgements}

This research has received funding from the European Research Council under the European Commission's Seventh Framework Programme (FP7/2007-2013) as ERC grant agreement no. 233366 (POPFULL), as well as from the Flemish Hercules Founda- tion as Infrastructure contract ZW09-06. Further funding was provided by the Flemish Methusalem Programme and by the Research Council of the University of Antwerp. We gratefully acknowledge Joris Cools for excellent technical support, Kristof Mouton for logistic support at the field site, thesis students Raphaël Vossen (University of Antwerp, Belgium) and Kübra Sönmezoglu (Marmara University, Turkey) as well as Dr. Isabele Sarzi Falchi (Instituto Florestal, Secretaria do Meio Ambiente/Governo do Estado de São Paulo, Brazil) for invaluable assistance with field work.

LS Broeckx and SPP Vanbeveren have equally contributed to this work.

\section{References}

AEBIOM (2010). European biomass statistics. European Biomass Association, Brussels, Belgium, pp. 75.

Al Afas N, Marron N, Van Dongen S, Laureysens I, Ceulemans R (2008). Dynamics of biomass production in a poplar coppice culture over three rotations (11 years). Forest Ecology and Management 255: 1883-1891. - doi: 10.1016/j.foreco .2007 .12 .010

Benetka V, Novotna K, Stochlova P (2014). Biomass production of Populus nigra L. clones grown in short rotation coppice systems in three different environments over four rotations. iForest 7: 232-238. - doi: 10.3832/ifor1162-007 Berhongaray G, El Kasmioui O, Ceulemans R (2013). Comparative analysis of harvesting machines on an operational high-density short rotation woody crop (SRWC) culture: one-process versus two-process harvest operation. Biomass and Bioenergy 58: 333-342. - doi: 10.1016/j. biombioe.2013.07.003

Binkley D, Camargo Campoe O, Gspaltl M, Forrester DI (2013). Light absorption and use efficiency in forests: why patterns differ for trees and stands. Forest Ecology and Management 288: 5-13. - doi: 10.1016/j.foreco.2011.11.002

Broeckx LS, Verlinden MS, Ceulemans R (2012). Establishment and two-year growth of a bio-energy plantation with fast-growing Populus trees in Flanders (Belgium): effects of genotype and former land use. Biomass and Bioenergy 42: 151-163. - doi: 10.1016/j.biombioe.2012.03.005 Broeckx LS, Verlinden MS, Berhongaray G, Zona D, Fichot R, Ceulemans R (2014a). The effect of a dry spring on seasonal carbon allocation and vegetation dynamics in a poplar bioenergy plantation. Global Change Biology Bioenergy 6: 473487. - doi: 10.1111/gcbb.12087

Broeckx LS, Fichot R, Verlinden MS, Ceulemans R (2014b). Seasonal variations in photosynthesis, intrinsic water-use efficiency and stable isotope composition of poplar leaves in a short-rotation plantation. Tree Physiology 34: 701-715. doi: 10.1093/treephys/tpu057

Bullard MJ, Mustill SJ, Carver P, Nixon PMI (2002). Yield improvements through modification of planting density and harvest frequency in short rotation coppice Salix spp. 2: Resource 
capture and use in two morphologically diverse varieties. Biomass and Bioenergy 22: 27-39. doi: 10.1016/S0961-9534(01)00055-1

Calfapietra C, Gielen B, Galema ANJ, Lukac M, De Angelis P, Moscatelli MC, Ceulemans R, Scarascia-Mugnozza G (2003). Free-air $\mathrm{CO}_{2}$ enrichment (FACE) enhances biomass production in a short-rotation poplar plantation. Tree Physiology 23: 805-814. - doi: 10.1093/treephys/23. 12.805

Cannell MGR (1989). Light interception, light use efficiency and assimilate partitioning in poplar and willow stands. In: "Biomass Production by Fast-Growing Trees" (Pereira JS, Landsberg JJ eds). Kluwer Academic Publisher, Dordrecht, The Netherlands, pp. 1-12. - doi: 10.1007/97894-009-2348-5 1

Cannell MGR, Milne R, Sheppard LJ, Unsworth MH (1987). Radiation interception and productivity of willow. Journal of Applied Ecology 24: 261-278. - doi: 10.2307/2403803

Cannell MGR, Sheppard LJ, Milne R (1988). Light use efficiency and woody biomass production of poplar and willow. Forestry 61: 125-136. - doi: 10.1093/forestry/61.2.125

Casella E, Ceulemans R (2002). Spatial distribution of leaf morphological and physiological characteristics in relation to local radiation regime within the canopies of 3-year-old Populus clones in coppice culture. Tree Physiology 22 1277-1288. - doi: 10.1093/treephys/22.18.1277

Ceulemans R, Deraedt W (1999). Production physiology and growth potential of poplars under short-rotation forestry culture. Forest Ecology and Management 121: 9-23. - doi: 10.1016/S03 78-1127(98)00564-7

Ceulemans R, McDonald AJS, Pereira JS (1996). A comparison among eucalypt, poplar and willow characteristics with particular reference to coppice, growth-modelling approach. Biomass and Bioenergy 11: 215-231. - doi: 10.1016/096 1-9534(96)00035-9

Deraedt W, Ceulemans R (1998). Clonal variability in biomass production and conversion efficiency of poplar during the establishment year of a short rotation coppice plantation. Biomass and Bioenergy 15: 391-398. - doi: 10.1016/S09619534(98)00045-2

Dillen SY, Marron N, Sabatti M, Ceulemans R, Bastien C (2009). Relationships among productivity determinants in two hybrid poplar families grown during three years at two contrasting sites. Tree Physiology 29: 975-987. - doi: 10.1093/tree phys/tpp036

Dillen SY, Vanbeveren S, Al Afas N, Laureysens I, Croes S, Ceulemans R (2011). Biomass production in a 15-year-old poplar short-rotation coppice culture in Belgium. Aspects of Applied Biology 112: 99-106. [online] URL: http:/www researchgate.net/profile/Stefan Vanbeveren/publication/268520412

Dimitriou I, Rosenqvist H, Berndes G (2011) Slow expansion and low yields of willow short rotation coppice in Sweden; implications for future strategies. Biomass and Bioenergy 35: 46134618. - doi: 10.1016/j.biombioe.2011.09.006
Don A, Osborne B, Hastings A, Skiba U, Carter MS, Drewer J, Flessa H, Freibauer A, Hyvönen $\mathrm{N}$, Jones MB, Lanigan GJ, Mander U, Monti A, Njakou Djomo S, Valentine J, Walter K, ZegadaLizarazu W, Zenone T (2011). Land-use change to bioenergy production in Europe: implications for the greenhouse gas balance and soil carbon. Global Change Biology Bioenergy 4: 372-391. doi: 10.1111/j.1757-1707.2011.01116.x

Dowell RC, Gibbins D, Rhoads JL, Pallardy SG (2009). Biomass production physiology and soil carbon dynamics in short-rotation-grown Populus deltoides and $P$. deltoides $\times P$. nigra hybrids. Forest Ecology and Management 257: 134-142. - doi: 10.1016/j.foreco.2008.08.023

European Council (2009). On the promotion of the use of energy from renewable sources and amending and subsequently repealing Directives 2001/77/EC and 2003/30/EC. Directive 2009/ 28/EC of the European Parliament and of the Council of 23 April 2009, Brussels, Belgium, pp. 47.

Fischer G, Prieler S, Van Velthuizen H, Berndes G, Faaij A, Londo M, De Wit M (2010). Biofuel production potentials in Europe: sustainable use of cultivated land and pastures, Part II: land use scenarios. Biomass and Bioenergy 34: 173-187. doi: 10.1016/j.biombioe.2009.07.009

Fischer M, Trnka M, Kucera J, Deckmyn G, Orság M, Sedlák P, Zalud Z, Ceulemans R (2013). Evapotranspiration of a high-density poplar stand in comparison with a reference grass cover in the Czech-Moravian highlands. Agricultural and Forest Meteorology 181: 43-60. - doi: 10.1016/j.agrformet.2013.07.004

Green DS, Kruger EL, Stanosz GR, Isebrands JG (2001). Light-use efficiency of native and hybrid poplar genotypes at high levels of intracanopy competition. Canadian Journal of Forest Research 31: 1030-1037. - doi: 10.1139/x01-041

Guidi W, Piccioni E, Bonari E (2008). Evapotranspiration and crop coefficient of poplar and willow short-rotation coppice used as vegetation filter. Bioresource Technology 99: 4832-4840. doi: 10.1016/j.biortech.2007.09.055

Heilman PE, Hinckley TM, Roberts DA, Ceulemans R (1996). Production physiology. In: "Biology of Populus and its Implications for Management and Conservation" (Stettler RF, Bradshaw HD, Heilman PE, Hinckley TM eds). NRC Research Press, Ottawa, ON, Canada, pp. 459-489. [online] URL: http://www.nrcresearchpress.com/ doi/abs/10.1139/9780660165066

Howe GT, Saruul P, Davis J, Chen THH (2000). Quantitative genetics of bud phenology, frost damage, and winter survival in an $F_{2}$ family of hybrid poplars. Theoretical and Applied Genetics 101: 632-642. - doi: 10.1007/s001220051525

IPCC (2014). Climate change 2014: mitigation of climate change. Contribution of working Group III to the Fifth Assessment Report of the Intergovernmental Panel on Climate Change (Edenhofer O, Pichs-Madruga R, Sokona Y, Farahani E, Kadner S, Seyboth K, Adler A, Baum I, Brunner S, Eickemeier P, Krieman B, Savolainen J, Schlömer S, Stechow C, Zwickel T, Minx Ceds J eds). Cambridge University Press, Cambridge, UK and New York, NY, USA, pp. 1075.

Isebrands JG, Nelson NO, Dickmann DI, Michael DA (1983). Yield physiology of short rotation intensively cultured poplars. Technical Report GTR-NC-91, USDA Forest Service, St. Paul, MN, USA, pp. 77-93.

Langeveld H, Quist-Wessel F, Dimitriou I, Aronsson P, Baum C, Schulz U, Bolte A, Baum S, Köhn J, Weih M, Gruss H, Leinweber P, Lamersdorf N, Schmidt-Walter P, Berndes G (2012). Assessing environmental impacts of short rotation coppice (SRC) expansion: model definition and preliminary results. Bioenergy Research 5: 621-635. - doi: 10.1007/s12155-012-9235-x

Larcher W (2003). Physiological plant physiology $\left(4^{\text {th }}\right.$ edn). Springer-Verlag, Berlin, Heidelberg, New York, pp. 513.

Larson PR, Isebrands JG (1972). The relation between leaf production and wood weight in firstyear root sprouts of two Populus clones. Canadian Journal of Forest Research 2: 98-104. - doi: 10.1139/x72-020

Liberloo M, Calfapietra C, Lukac M, Godbold D, Luos ZB, Polle A, Hoosbeek MR, Kull O, Marek M, Raines C, Rubino M, Taylor G, ScarasciaMugnozza G, Ceulemans R (2006). Woody biomass production during the second rotation of a bio-energy Populus plantation increases in a future high $\mathrm{CO}_{2}$ world. Global Change Biology 12 1094-1106. - doi: 10.1111/j.1365-2486.2006.01 118.x

Liberloo M, Dillen SY, Calfapietra C, Marinari S, Luo ZB, De Angelis P, Ceulemans R (2005). Elevated $\mathrm{CO}_{2}$ concentration, fertilization and their interaction: growth stimulation in a shortrotation poplar coppice (EUROFACE). Tree Physiology 25: 179-189. - doi: 10.1093/treephys/ 25.2.179

Linderson ML, Iritz Z, Lindroth A (2007). The effect of water availability on standlevel productivity, transpiration, water use efficiency and radiation use efficiency of field-grown willow clones. Biomass and Bioenergy 31: 460-468. - doi: 10.1016/j.biombioe.2007.01.014

Lindroth A, Verwijst T, Halldin S (1994). Wateruse efficiency of willow: variation with season, humidity and biomass allocation. Journal of Hydrology 156: 1-19. - doi: 10.1016/0022-1694(94) 90068-X

Medlyn BE (1998). Physiological basis of the light use efficiency model. Tree Physiology 18: 167-176. - doi: 10.1093/treephys/18.3.167

Michael DA, Isebrands JG, Dickmann DI, Nelson ND (1988). Growth and development during the establishment year of two Populus clones with contrasting morphology and phenology. Tree Physiology 4: 139-152. - doi: 10.1093/treephys/4 .2 .139

Paris P, Mareschi L, Sabatti M, Pisanelli A, Ecosse A, Nardin F, Scarascia-Mugnozza GE (2011). Comparing hybrid Populus clones for SFR across northern Italy after two biennial rotations: survival, growth and yield. Biomass and Bioenergy 35: 1524-1532. - doi: 10.1016/j.biombioe. 2010.12 .050 
Pellis A, Laureysens I, Ceulemans R (2004). Genetic variation of the bud and leaf phenology of seventeen poplar clones in a short rotation coppice culture. Plant Biology 6: 38-46. - doi 10.1055/s-2003-44746

Petzold R, Schwärzel K, Feger KH (2010). Transpiration of a hybrid poplar plantation in Saxony (Germany) in response to climate and soil conditions. European Journal of Forest Research 130: 695-706. - doi: 10.1007/s10342-010-0459-z

Proe MF, Griffiths JH, Craig J (2002). Effects of spacing, species and coppicing on leaf area, light interception and photosynthesis in short rotation forestry. Biomass and Bioenergy 23: 315-326. doi: 10.1016/S0961-9534(02)00060-0

Rae AM, Robinson KM, Street NR, Taylor G (2004). Morphological and physiological traits influencing biomass productivity in short-rotation coppice poplar. Canadian Journal of Forest Research 34: 1488-1498. - doi: 10.1139/x04-033 Rosenquist H, Roos A, Ling E, Hektor B (2000). Willow growers in Sweden. Biomass and Bioenergy 18: 137-145. - doi: 10.1016/S0961-9534 (99)00081-1

Ruimy A, Dedieu G, Saugier B (1994). Methodology for the estimation of terrestrial net primary production from remotely sensed data. Journal of Geophysical Research - Atmospheres 99: 52635283. - doi: 10.1029/93JD03221

Scarascia-Mugnozza GE, Isebrands JG, Hinckley TM, Stettler RF (1989). Dynamics of light inter- ception, leaf area and biomass production in Populus clones in the establishment year. Annals of Forest Science 49: 515-518. - doi: 10.1051/ forest:198905ART0116

Serup H, Kofman PD, Falster H, Gamborg C, Gundersen P, Hansen L, Heding N, Houmann H, Nikolaisen L, Thomsen IM, Carroll J (2005). Wood for energy production, Irish edition. COFORD, National Council for Forest Research and Development, Dublin, Ireland, pp. 72. [online] URL: https://inis.iaea.org/search/search.aspx?ori g_q=RN:31004157

Sinclair TR, Horie T (1989). Leaf nitrogen, photosynthesis and crop radiation use efficiency: a review. Crop Science 29: 90-98. - doi: 10.2135/ cropsci1989.0011183X002900010023x

Taylor G, Ceulemans R, Ferris R, Gardner SDL, Shao BY (2001a). Increased leaf area expansion of hybrid poplar in elevated $\mathrm{CO}_{2}$. From controlled environments to open-top chambers and to FACE. Environmental Pollution 115: 463472. - doi: 10.1016/S0269-7491(01)00235-4 Tharakan PJ, Volk TA, Nowak CA, Ofezu GJ (2008). Assessment of canopy structure, light interception, and light-use efficiency of first year regrowth of shrub willow (Salix sp.). Bioenergy Research 1: 229-238. - doi: 10.1007/s12155008-9023-9

Tschaplinski TJ, Blake TJ (1989). Water relations, photosynthetic capacity and root/shoot partitioning of photosynthate as determinants of produc- tivity in hybrid poplar cultivars. Canadian Journal of Botany 67: 1689-1697. - doi: 10.1139/b8 9-213

Turok J, Lefèvre F, Cagelli L, Vries SD (1996). Populus nigra network. Report of the second meeting, Casale Monferrato (Italy) 10-12 Sep 1995. International Plant Genetic Resources Institute, Rome, Italy, pp. 26.

Verlinden MS, Broeckx LS, Van den Bulcke J, Van Acker J, Ceulemans R (2013). Comparative study of biomass determinants of 12 poplar ( $\mathrm{Po}$ pulus) genotypes in a high-density short-rotation culture. Forest Ecology and Management 307: 101-111. - doi: 10.1016/j.foreco.2013.06.062

Xu L, Baldocchi DD (2003). Seasonal trends in photosynthetic parameters and stomatal conductance of blue oak (Quercus douglasii) under prolonged summer drought and high temperature. Tree Physiology 23: 865-877. - doi: 10.1093/ treephys/23.13.865

\section{Supplementary Material}

Appendix 1 - Genotypic, parentage and plantation averages for maximum leaf area index $\left(\mathrm{LAI}_{\max }\right)$, leaf area duration (LAD), aboveground woody biomass productivity (AGWB), intercepted radiation $\left(I_{\text {int }}\right)$ and radiation use efficiency (RUE).

Link: Broeckx_1457@suppl001.xlsx 